\title{
Stoichiometric Ratio in Calixarene Complexes
}

\author{
Flor de María Ramírez and Irma García-Sosa \\ Instituto Nacional de Investigaciones Nucleares \\ México
}

\section{Introduction}

Stoichiometry is a fundamental concept in chemistry that refers to the ratios of products and reactants in any chemical reaction. It is an important concept in both chemical reactions and biochemical processes. A stoichiometric ratio represents the relationship among the elements or molecules present in an equation. Using the correct stoichiometric amount of reactant will yield the maximum amount of product under the proper thermodynamic and kinetic conditions.

This chapter will be focused on the latest research, from our and other labs, on the determination of stoichiometric ratios for complexed species formed between substrates and calixarene receptors, the influence of size, conformation and functionalization site of calixarenes on the stoichiometry, as well as solvent effects and the stability of the complexes in the liquid and solid states. No formation (stability) constants will be discussed, although in some cases these could be mentioned.

Particular attention will be paid to the experimental methods used for stoichiometry determination. Furthermore, complexed calixarene molecules in 1:1, 1:2 and 2:1 (Substrate:Calixarene) stoichiometries calculated by Augmented MM3 and CONFLEX semiempirical procedures, and other computational calculations will be included.

The enormous number of sophisticated functionalized calixarenes published so far, forced us to be selective. Therefore, our attention will be devoted to the stoichiometry of complexes formed with parent calixarenes (Gutsche, 1989, 1998, Mandolini \& Ungaro 2000) functionalized at the lower and upper rims, with linear arms, that were first reported between 1999 and 2011.

\section{A brief overview of calixarenes}

Calixarenes are an important group of macrocycles, considered the third best host (receptors) molecules after cyclodextrins and crown ethers (Shinkai, 1993). They are prepared by condensation reactions between para-substituted phenols and formaldehyde (Gutsche, 1989). Here, we focus on conventional endo-calixarenes, which have a lipophilic cavity and two rims: the polar lower rim and the apolar upper rim that provides an unusual flexibility to the calixarene that can be modulated by adjusting cavity size and the rim substituents size. Its basket-like structure, with a lipophilic cavity made up of aromatic 
nuclei and easily modified rims, has attracted the attention of many theoretical and experimental researchers.

With exceptions, macrocycle flexibility, i.e. conformational movement, increases with size. Calix $[n]$ arenes (where $n$ stands for the number of aryl groups in the macrocycle) with $n=4$ to 20 have been synthesized (Gutsche, 1998), but only the smaller cycles $(n=4,6$ and 8$)$ have been thoroughly studied. Calixarenes are versatile macrocycles with almost unlimited properties (Böhmer, 1995); they are excellent scaffolds since their conformation can be adapted to potential guests, and they can be selectively functionalized at three sites (Asfari et al., 2001; Mandolini \& Ungaro, 2000). Most commonly, specific groups or substituents called pendant arms are added to the rims to impart a specific function.

Calixarenes are very attractive to researchers from numerous science and technology fields (Fig. 1). A vast array of functionalized calixarenes have been reported over the last decade (Alexandratos and Natesan, 2000; Gutsche, 1998; Lumetta et al., 2000; Mandolini and Ungaro, 2000; Mokhtari et al., 2011a, 2011b; Sliwa, 2002; Sliwa \& Girck, 2010; Talanova, 2000). The challenge is to quickly synthesize suitable calixarenes on a large scale with minimal workup.

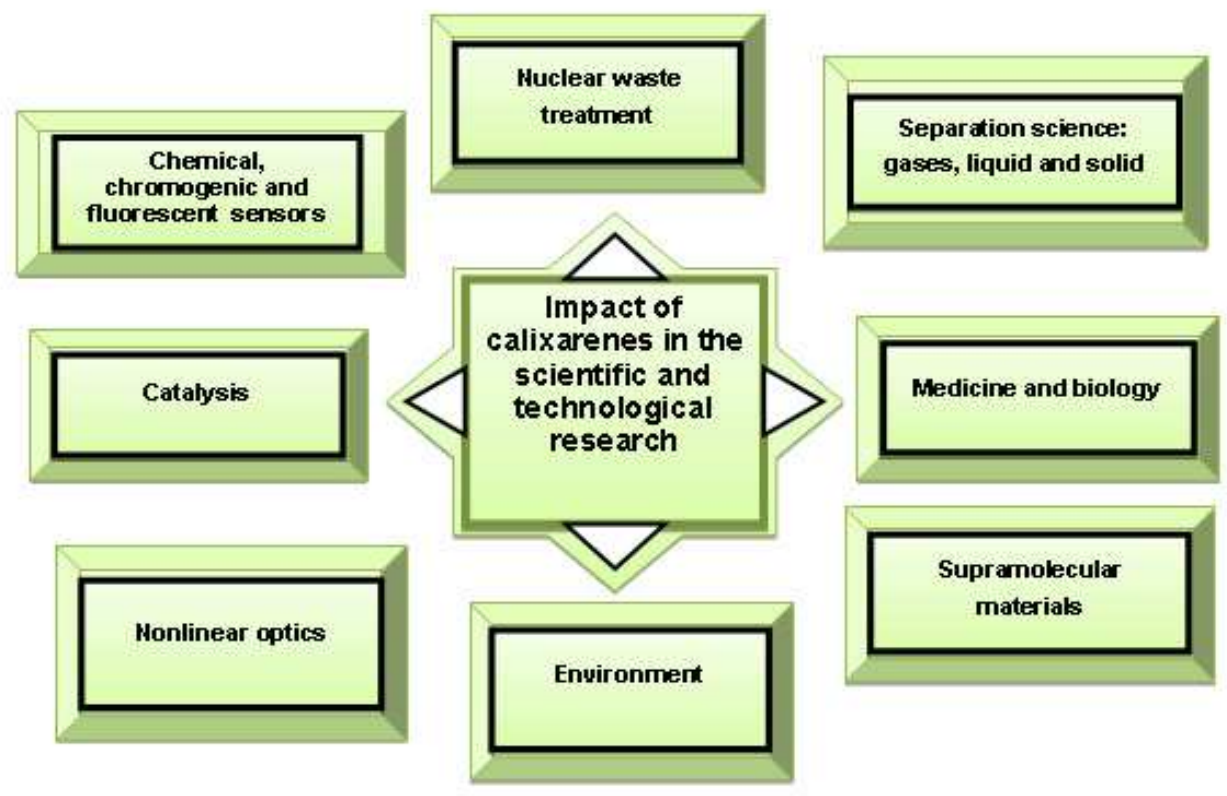

Fig. 1. Applications for calixarenes in science and technology.

In Fig. 2, a selection of recently reported calixarenes are presented. 

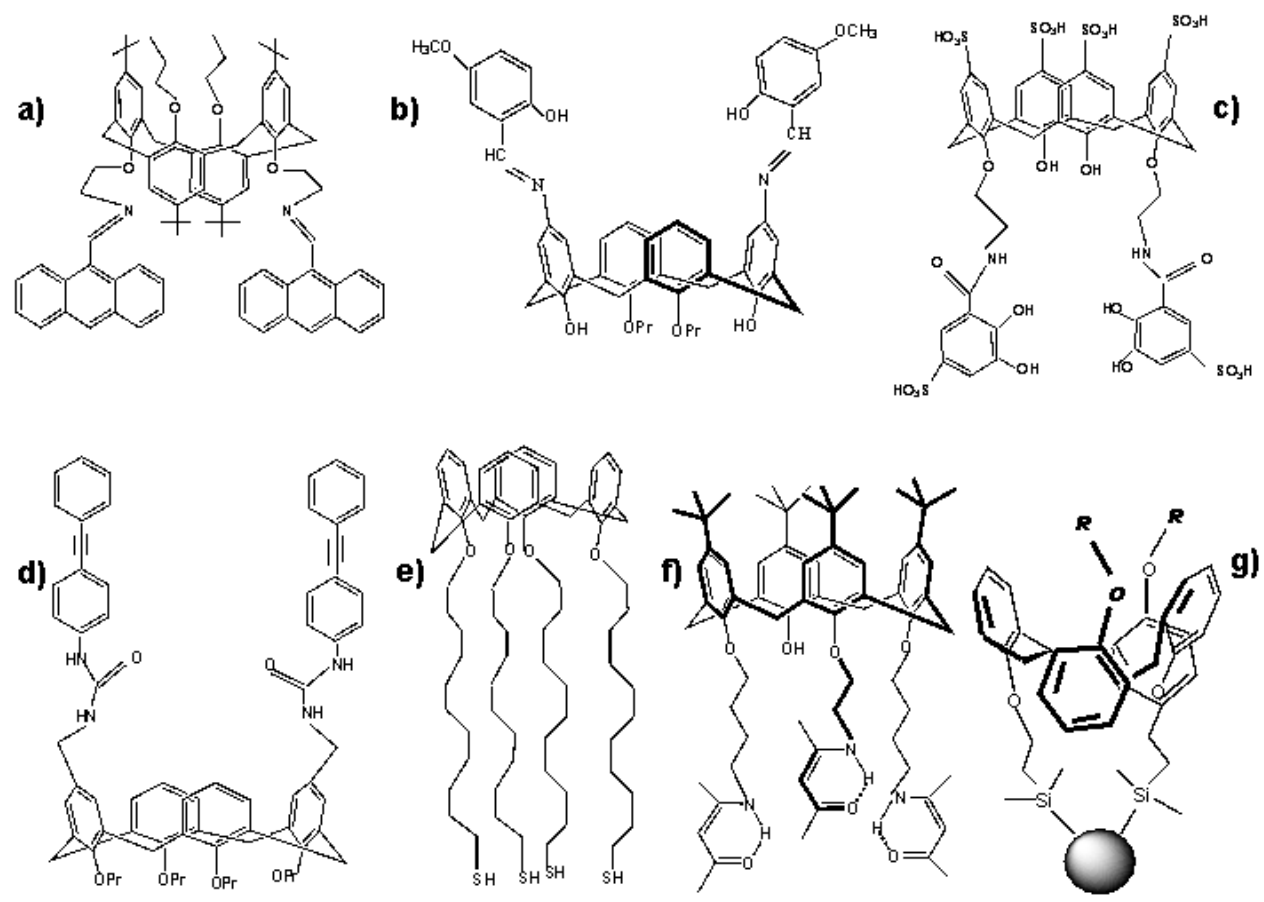

Fig. 2. Some interesting calixarene molecules built with ChemDraw Ultra 10.0 software. a) Zheng et al. (2010), b) Liang et al. (2007), c) Leydier et al. (2008), d) Bew et al. (2010), e) Snejdarkova et al. (2010), f) Sliwa\& Deska, (2008), g) Sliwka-Kaszynska et al. (2009), articles cited by Mokhtari et al., 2011b.

\section{Finding the stoichiometric ratio}

The method of continuous variation involves a series of isomolar solutions of two reactants. It is one commonly used experimental mixing technique for determining formula and formation constants of complexes. The method is also known as Job's method, for his general development of spectrophotometric measurement techniques (Gil \& Oliveira, 1990). However, it was Ostromisslensky in 1911 who (Hill \& MacCarthy, 1986; Likussar \& Boltz, 1971) first employed the method to establish the 1:1 stoichiometry of the adduct formed between nitrobenzene and aniline. Other methods, such as molar ratios and titration in a single flask, are also currently used to investigate the stoichiometry of complexes.

\subsection{Job's method}

Job's method is carried out in a batch mode (series of solutions) by mixing aliquots of two equimolecular stock solutions of two components (metal and ligand, or organic substrate and organic receptor) and diluting to a constant volume to get solutions with identical total molar concentrations but different mole fractions. The sum of the two components analytical 
concentration is constant while the Component 1:Component 2 ratio varies from flask to flask. Job's method is based on plotting measured absorbance (corrected for reactants absorbance) against the mole fraction of one single component. For stable complexes, the plot is a triangle, with the apex indicating the complex composition. For a moderately stable complex, the stoichiometry can be obtained from the intersection point of the curve tangents, this approximation being valid only for symmetrical plots (e.g. 1:1; 2:2). Weak complexes generally show a very curved plot.

This method works well for reactions where a single equilibrium, or simple equilibriums exist uninfluenced by ionic strength; no more than three species (two reactants and the product) can be present in solution and their complexes have to be very stable. Job's method may be applied to stoichiometric determination in two ways. The Standard Method was described above. The modified Limiting Reagent Method uses a series of

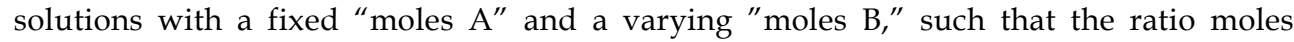
B:moles $A$, goes from 0 to a value known to be larger than $x$ ( $x$ equal to moles of $B$ at intersection/(total moles of A plus B minus moles of B at intersection). The amount of product in each solution is then measured. Once the amount of $B$ exceeds the stoichiometrically required amount, A becomes the limiting reagent and the amount of the formed product remains constant.

According to stoichiometric theory, the limiting reagent controls the yield, and the greatest yield is always produced at the stoichiometric equivalence point. The maximum amount of product should occur at the stoichiometric ratio that can be justified both intuitively and mathematically. For both methods, 8-15 experimental data points are required to determine the stoichiometry. The method can be applied to parameters obtained from techniques other than typical spectrophotometry, e.g. luminescence, nuclear magnetic resonance, calorimetry, conductometry.

Job's method has serious limitations for complex reactions systems where the number of species is larger than three. In these cases, two or more complexed species with different stoichiometries are formed, and/or the stability of the complexes is moderate. Moreover, the method fails when the formed complexes are only weakly stable. A simulation program (Gil \& Oliveira, 1990) for reaction equilibriums has improved application of Job's method to more complicated systems.

\subsection{Spectrophotometric titration}

There are several experimental methods to determine stoichiometries for systems with multiple complex species in solution. Spectrophotometric titration monitored by UV/Vis is largely used because UV/Vis spectrophotometers are widely available and inexpensive. The radiant energy absorption of a solution is measured spectrophotometrically after each increment of titrant, but the evaluation is somewhat limited by the solubility of the reactants (but not the products) in water and/or organic solvent.

In macrocyclic coordination chemistry equimolar solutions of the reactants in the same solvent with the same ionic strength are prepared, and two titrations are carried out, titrating the receptor with the substrate and the substrate with the receptor, respectively. In the former, a fixed volume of the receptor solution is titrated by adding varying volumes of the substrate solution. After each addition the UV/Vis spectrum is recorded. The titrant is 
added until the absorbance at the analyzed wavelength does not change, or until a new band appears. Approximately 30 spectra are required, or enough data collected until a molar ratio $[S] /[R] \geq 4$ is reached. Specfit or Hyperquad software is used for stoichiometry evaluation.

Spectra, solution concentrations, initial volume, aliquot number and volumes, and the total final volume are fed into the Specfit software. Factor analysis reveals the number of absorbing species, and the data are fitted to models to obtain the stoichiometry of the species and their stability constants. The same steps are followed if a fixed volume of the substrate solution is titrated with a variable volume of the receptor solution.

In the case of calixarene complexes, the titration can be followed by analyzing changes in the physicochemical properties of the receptor or the substrate as the complex is formed (e.g. absorbance, luminescence, NMR chemical shifts, calorimetric changes).

\section{Spectroscopic techniques}

$\mathrm{UV} / \mathrm{Vis},{ }^{1} \mathrm{H}^{\prime} \mathrm{NMR}$, MS (mass spectrometry) and luminescence are the spectroscopic techniques that are most used for the elucidation of stoichiometry in calixarene complexes with organic or metallic substrates. In general, spectroscopic techniques are complementary, but if the solution contains only one complex species data from a single technique analyzed by Job or/and molar ratio methods may be sufficient. In these cases sometimes only 8 experimental points are required for a Job plot. However, if the solution contains more than two complex species, at least two different techniques and software packages are needed; in some cases the evaluation of stability constants is required to confirm the existence of a complex species in the determined stoichiometry.

The stoichiometry of isolated calixarene complexes in the solid state can be elucidated by microelemental analysis or, if possible, by its X-ray structure. If the complexes dissolve without decomposition, NMR and MS measurements are extremely useful for confirming stoichiometry.

\section{Calixarene complexation}

Calixarenes can interact with neutral, cationic and anionic organic substrates as well as metal ions; they are sometimes called "molecular baskets" because of this diverse capacity. Calixarenes are neutral but can act as cationic and anionic receptors if adequately functionalized (Asfari et al., 2001; Lumetta et al., 2000; Mandolini \& Ungaro, 2000; Mokhtari et al., 2011a, 2011b; Sliwa \& Girck, 2010). The calixarene-substrate interaction is illustrated in Fig. 3. Molecular recognition, the strength of the interaction between calixarenes and their substrates and thermodynamic and kinetic factors rule the complexes formation. It is important to keep in mind that the donating ability of solvents plays an import role (Asfari et al., 2001; Mandolini \& Ungaro, 2000) in complex stability.

In organic-calixarene complexes (Fig. 3, top right), noncovalent interactions such as hydrogen bonds, $\Pi$ - hydrogen bonds, hydrophobic interactions, and cation- $\pi$ and $\mathrm{CH}-\pi$ interactions are the main driving forces that allow stable complexes to form in the liquid and solid states (Asfari et al., 2001; García-Sosa \& Ramírez, 2010; Mandolini \& Ungaro, 2000). 
In metal-calixarene complexes (Fig. 3, bottom right), the coordination ability of the calixarene toward the metal ion determines complex formation. Ionic and covalent interactions dominate complex formation and define calixarene complex properties including stoichiometry.
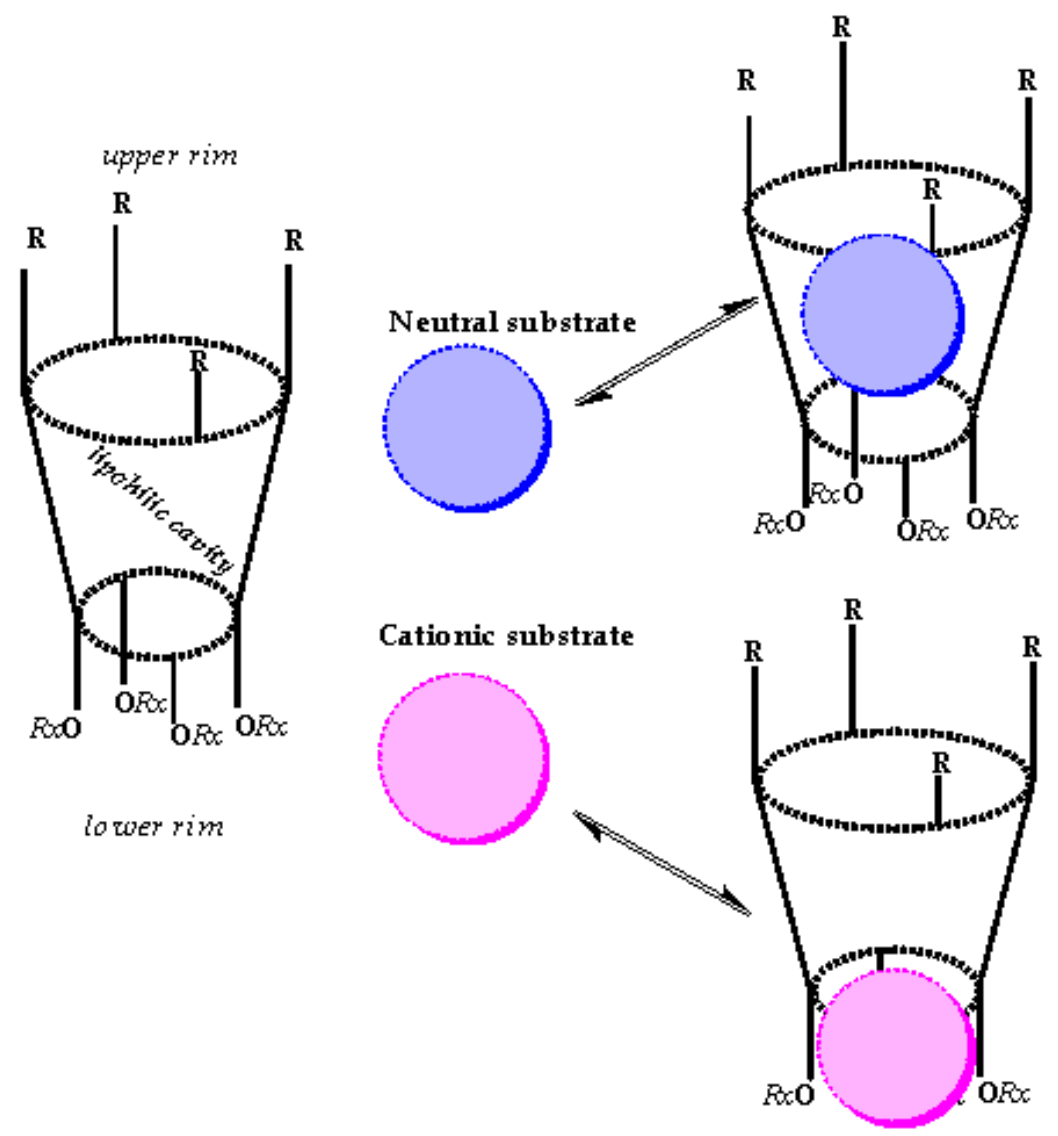

RECEPTOR

COMP LEXES

Fig. 3. Schematic representation of calixarene complexation with neutral and cationic substrates.

\subsection{Stoichiometry in calixarene complexes with organic substrates in solution}

There are a great number of calixarene complexes that are formed from functionalized calixarenes and organic substrates. Investigations into receptor-substrate recognition in solution afford fundamental knowledge and describe environmental, biological and medical 
applications. However, to the best of our knowledge, little work has been done related to stoichiometric studies of calixarene complexes for biomedical applications.

Here, we discuss some illustrative investigations.

\subsubsection{Stoichiometric ratio with neutral calixarenes}

Mohammed-Ziegler et al. (2003) investigated complex formation between chromogenic capped calix[4]arene derivatives comprising indophenol indicator group(s) and aliphatic amines in ethanol using UV/Vis spectroscopy. Job's method was applied to quantify the spectral changes using various molar amine/calixarene ligand ratios by maintaining a constant ligand concentration $(\lambda \max =520-534 \mathrm{~nm})$ and varying the amine concentration. A new band emerged at 652-667 nm indicating complexation and adducts with a 1:1 stoichiometry were determined. The study indicated the formation of strong polar supramolecular complexes of calix[4]arenes capped by diamide bridges with the amines, stabilized by various types of host-guest interactions and by steric effects.

Zielenkiewicz et al. (2005) have thoroughly studied the complexation of isoleucine by phosphorylated calix[4]arene in methanol. Calorimetry, NMR and UV/Vis (Job's method) spectroscopy, as well as molecular modeling methods, were used. In methanol, amino acids occur primarily in the form of zwitterions $\left[\mathrm{H}_{3} \mathrm{~N}^{+} \mathrm{CH}(\mathrm{R}) \mathrm{CO}_{2}^{-}\right]$, with a protonated amino acid and a dissociated carboxylic group. The association constants determined by spectroscopy agree with data obtained by calorimetry: 25,000 for a 1:1 complex and 1700 for 1:2 isoleucine:calixarene complexes, respectively. The formation of the former is driven by favorable changes both in enthalpy and entropy during complexation while the 1:2 complex is of entropic origin.

The 1:2 complex is the result of inclusion of the amino acid's alkyl chain into the cavity of one calixarene molecule and interaction of the amino acid amino group with the phosphoryl group of a second calixarene. The more stable 1:1 complex points to electrostatic interactions between the positively charged ammonium cations of the amino acid and the phosphoryl groups of the calixarene. The phosphoryl groups appear to serve as the anchoring points for the positively charged ammonium cations of the amino acid, thus leading to a more stable inclusion complex. Complexation of isoleucine also takes place through insertion of the aliphatic moiety of the substrate molecule into the calixarene cavity. Electrostatic interactions are the dominant forces in the complexation process. Molecular modeling results fit extraordinary well with experimental values, corroborating the 1:1 and 1:2: isoleucine:calixarene(s) stoichiometries.

Halder et al. (2010) investigated the effective and selective noncovalent interactions between fullerenes $\left(C_{60}\right.$ and $\left.C_{70}\right)$ and para-tert-butylcalix[6]arene in toluene by UV/Vis and NMR methods. Both $\mathrm{C}_{60}$ and $\mathrm{C}_{70}$ form ground state noncovalent complexes with the calixarene; according to UV/Vis measurements, the complexation process is initiated by charge transfer transition. From Job's method, it was observed that both $\mathrm{C}_{60}$ and $\mathrm{C}_{70}$ form stable complexes with the calixarene ligand in a 1:1 stoichiometry. According to the binding constants, the calixarene bound strongly and selectively to $C_{70}$, compared with $C_{60}, K=110,000$ and 32,400 $\mathrm{dm}^{3} \mathrm{~mol}^{-1}$, respectively. Proton NMR measurements support a strong complexation between $\mathrm{C}_{70}$ and the calixarene ligand. 


\subsubsection{Stoichiometric ratio with charged calixarenes}

Kunsági-Máté et al. (2004) investigated complex formation between $\mathrm{C}_{60}$ fullerene (dissolved in toluene) and water-soluble hexasulfonated calix[6]arenes functionalized with sulfonates in the upper rim. Photoluminescence (PL) measurements and Job's method were used for this investigation. The stoichiometry of the complex was 1:1, and related quantum chemical calculations demonstrated that the $\mathrm{C}_{60}$ fullerene is located deep within the cavity of the calixarene. This observation makes this calixarene a promising candidate for overcoming the natural water-repulsive character of $\mathrm{C}_{60}$ fullerene and could improve the application of fullerenes to biochemical processes.

Zhou et al. (2008) used spectrofluorometric titrations to investigate the inclusion behavior of $p$-( $p$-carboxyl benzeneazo) calix[4]arene with norfloxacin (fungicide) in sodium acetateacetic acid buffer solution. The fluorescence results indicated a 1:1 complex stoichiometry. Stoichiometry was also evaluated by applying Job's method to fluorescence measurements to verify the 1:1 inclusion complex. Hydrogen bonding and structural matching effects were proposed to play important roles in the formation of the calixarene-norfloxacin complex in water. Furthermore, various factors affecting the inclusion process, such as $\mathrm{pH}$ value, ionic strength and surfactants, were examined in detail; the results corroborated the formation of this inclusion complex. The nature of the fungicide-calixarene interaction was mainly electrostatic. This investigation is crucial, since norfloxacin is a third-generation synthetic antibacterial fluoroquinolone agent that is used in the treatment of urinary and respiratory tract infections and gastro-intestinal and sexually transmitted diseases. Therefore, azocalix $[n]$ arenes and its inclusion compounds may have potential biological and medical applications.

The effect of adding a macrocycle such as para-sulfonatocalix[6]arene on the fluorescence of benzoimidazolic fungicides such as Benomyl (BY) and Carbendazim (CZ) has been studied by Pacioni et al. (2008) using spectrofluorimetric titrations. Benomyl (BY) and Carbendazim (CZ) interact with para-sulfonatocalix[6]arene to form complexes. Calixarene enhanced the fluorescence of BY in water at $\mathrm{pH} 1.000$ and $25^{\circ} \mathrm{C}$. An inclusion complex with 1:1 stoichiometry was formed with the pesticide. The nature of the interactions was mainly electrostatic, i.e. cation- $\Pi$ and ion-ion interactions between the cationic BY and sulfonate groups. The use of macrocyclic nanocavities, compared with other methods, is a very good alternative to determine BY residues in water and fruit samples at low levels, with better or in the same order. The complexation of the neutral $\mathrm{CZ}$ occurs at $\mathrm{pH}$ 6.994. Two complexes with 1:1 and 1:2 stoichiometries were formed; the latter complex was less fluorescent than the free CZ. п-п stacking and hydrogen bonding are the main driving forces for the 1:1 and 1:2 complexes.

Organic quaternary ammonium ions have been of great interest in molecular recognition studies; paraquat (1,1'-dimethyl-4,4'-bipyridinium dichloride) is an example. Pierro et al. (2009) investigated the conformation fitting of tetramethoxy-para-carboxylatocalix[4]arene and tetrapropiloxi-para-carboxylatocalix[4]arene to paraquat in a $\mathrm{CDCl}_{3 /} \mathrm{CD}_{3} \mathrm{OD}$ mixture using NMR measurements. This study demonstrated that tetrapropiloxi-paracarboxylatocalix[4]arene and paraquat formed a stable complex with a 1:1 stoichiometry, as estimated by a Job plot. NMR measurements indicated that upon complexation the $C_{2 v}$ 
structure of the free calixarene switches to an opposite $C_{2 v}$ pinched-cone conformation, with the two carboxylato-bearing rings pointing inward the calixarene cavity to maximize electrostatic and van der Waals interactions with the cationic paraquat. These adaptive conformational changes were fully confirmed by molecular modeling. The complexation of paraquat with tetrametoxi- para-carboxylatocalix[4]arene was also monitored with Diffusion-Ordered Spectroscopy (DOSY) NMR. DOSY has been particularly used in the characterization of host-guest systems in solution. The results indicated the formation of a complex in a 1:1 stoichiometry; in this complex, the calixarene was in the cone conformation while the free calixarene was predominantly in the partial-cone conformation.

Methiocarb [3,5-dimethyl-4-(methylthio) phenyl methylcarbamate] is one of the mostly important N-methylcarbamate pesticides, used worldwide in agriculture and health programs. Ding et al. (2011) investigated the complexation between tetrabutyl ether derivatives of p-sulfonatocalix[4]arene $(\mathrm{SC} 4 \mathrm{Bu})$ and methiocarb by fluorescence spectrometry in a mixture of water and DMSO. It was observed that upon the addition of methiocarb, the fluorescence intensity of SC4Bu was quenched and a slight red shift was observed for the maximum emission peak, which is indicative of a calixarene-methiocarb interaction. The results indicated that the SC4Bu-methiocarb complex was formed in a 1:1 mole ratio and that the electrostatic effect is not the main driving force. Using a modeling package it was proposed that complexation was an "external" inclusion process and that the hydrogen bonding between the methyl $\mathrm{H}$ atom of methiocarb and the sulfonate of SC4Bu facilitates the formation of this SC4Bu-methiocarb complex in a 1:1 stoichiometry. This study provides useful information for applying calixarenes to pesticide detection.

\subsection{Stoichiometry in calixarene complexes formed with organic substrates in solid state}

For years, organic frameworks have been suggested as promising gas storage substrates, but purely organic molecular crystals have received little attention. Atwood et al. (2005) studied the absorption of methane in p-tert-butylcalix[4]arene at room temperature and pressures of one atmosphere and lower. The results, supported by purely size-shape considerations, suggest that it is possible to accommodate at least two $\mathrm{CH}_{4}$ molecules within each dimeric capsule (i.e., calixarene:substrate $=1: 1$ ). On the basis of this assumption, preliminary results indicate that on average, at $0.54 \mathrm{~atm}, 14 \%$ of capsules are occupied by two molecules of methane. The results demonstrate that low-density organic systems do indeed deserve consideration as potential sorbants for volatile gases, and that such sorption processes can occur under desirable conditions close to standard temperature and pressure.

Ferreira et al. (2010) studied the inclusion of biacetyl within p-tert-butylcalix[n=4,6]arenes in powdered solid samples using luminescence and diffuse reflectance. Lifetime distribution analysis of the phosphorescence of both complexes suggested endo-inclusion calixarene complexes with p-tert-butylcalix[n=4]arene, and exo-inclusion calixarene complexes with $\mathrm{p}$ tert-butylcalix[n=6]arene. Although it is not explicit, the stoichiometry of the inclusion complexes seems to be 1:1.

Table 1 summarizes the stoichiometric ratio of some of the discussed organic complexes in solution and in the solid state. 


\begin{tabular}{|c|c|c|c|}
\hline Organic Substrate/calixarene & Technique & $\begin{array}{l}\text { Method/ } \\
\text { stoichiometry (M:L) }\end{array}$ & References \\
\hline $\begin{array}{l}\text { Aliphatic amines } \\
\text { /chromogenic capped } \\
\text { calix[4]arene derivatives }\end{array}$ & $\begin{array}{l}\mathrm{UV} / \mathrm{Vis} \text { titration } \\
\text { in ethanol }\end{array}$ & Job's Method/(1:1) & $\begin{array}{l}\text { Mohammed- } \\
\text { Ziegler, et al. } \\
\text { (2003) }\end{array}$ \\
\hline \multirow[b]{2}{*}{$\begin{array}{l}\text { Isoleucine(peptide)/ } \\
\text { phosporylated calix[4]arene. }\end{array}$} & $\begin{array}{l}\text { Insight II } \\
\text { package }\end{array}$ & $\begin{array}{l}\text { Molecular } \\
\text { Modeling / (1:1) }\end{array}$ & \multirow[t]{2}{*}{$\begin{array}{l}\text { Zielenkiewicz } \\
\text { et al. (2005) }\end{array}$} \\
\hline & $\begin{array}{l}\text { Calorimetry; } \\
\text { NMR titration } \\
\text { Methanol }\end{array}$ & $\begin{array}{l}\text { Job's Method/ } \\
(1: 1,1: 22: 1 ; 1: 1) \\
\text { /Modeling }\end{array}$ & \\
\hline $\begin{array}{l}\text { Norfloxacin } / p \text {-(p-carboxyl } \\
\text { benzene-azo) calix[4]arene }\end{array}$ & $\begin{array}{l}\text { Fluorescence } \\
\text { titration }\end{array}$ & Job's Method /(1:1) & $\begin{array}{l}\text { Zhou et al. } \\
\text { (2008). }\end{array}$ \\
\hline $\begin{array}{l}\mathrm{C}_{60} \text { fullerene / } \\
\text { sulfonated calixarene }\end{array}$ & $\begin{array}{l}\text { Fluorescence } \\
\text { titration }\end{array}$ & Job's Method /(1:1) & $\begin{array}{l}\text { Kunsági- } \\
\text { Máté et al. } \\
(2004)\end{array}$ \\
\hline $\begin{array}{l}\text { Adenine, guanine, cytosine, } \\
\text { thymine / calixarene- } \\
\text { D2EHPA }\end{array}$ & $\begin{array}{l}\text { Liquid-liquid } \\
\text { extraction }\end{array}$ & Job's Method/(1:1) & $\begin{array}{l}\text { Shimojo \& } \\
\text { Goto (2005). }\end{array}$ \\
\hline $\begin{array}{l}\text { fullerenes }\left(\mathrm{C}_{60} \text { and } \mathrm{C}_{70}\right) \\
\text { / para-tert-butylcalix[6]arene }\end{array}$ & $\begin{array}{l}\text { UV/Vis titration } \\
\text { toluene }\end{array}$ & Job's Method (1:1) & $\begin{array}{l}\text { Halder et al. } \\
(2010)\end{array}$ \\
\hline $\begin{array}{l}\text { Benomyl (BY) and } \\
\text { Carbendazim (CZ)/ } \\
\text { para-sulfonatocalix[6]arene. }\end{array}$ & $\begin{array}{l}\text { fluorescence } \\
\text { titration }\end{array}$ & $\begin{array}{l}\text { Job's Method / } \\
\text { BY(1:1), CZ(1:1, 1:2) }\end{array}$ & $\begin{array}{l}\text { Pacioni, et al. } \\
\text { (2008). }\end{array}$ \\
\hline Methane/calixarene & X-ray diffraction & 1:1 also modeled & $\begin{array}{l}\text { Atwood et al. } \\
(2005)\end{array}$ \\
\hline $\begin{array}{l}\text { paraquat / tetraalquiloxi- } \\
\text { para-carboxylatocalix[4]arene }\end{array}$ & $\begin{array}{l}\text { NMR titration/ } \\
\mathrm{CDCl}_{3 /} \mathrm{CD}_{3} \mathrm{OD}\end{array}$ & Job's Method(1:1) & $\begin{array}{l}\text { Pierro et al. } \\
(2009)\end{array}$ \\
\hline $\begin{array}{l}\text { N-methylcarbamate/para- } \\
\text { sulfonatocalix[4]arene }\end{array}$ & $\begin{array}{l}\text { Fluorescence } \\
\text { titration/ } \\
\mathrm{H}_{2} \mathrm{O}-\mathrm{DMSO}\end{array}$ & $\begin{array}{l}\text { Molecular } \\
\text { Modeling (1:1) }\end{array}$ & $\begin{array}{l}\text { Ding et al. } \\
\text { (2011) }\end{array}$ \\
\hline
\end{tabular}

Table 1. Stoichiometry of organic calixarene species, in solution and in the solid state, and the used techniques for their identification and determination.

Garcia-Sosa \& Ramírez (2010) found that para-tert-butylcalix[6]arene and para-tertbutylcalix[8]arene form stable 1:1 complexes with paraquat dichloride (PQ) in the solid state (the complexes were studied in liquid and solid states). The biexponential decay of luminescence and lifetimes proved that the quaternary ammoniums (quats) of the paraquat were not in the same environment for both complexes. This fact correlated with molecular models, since two de-excitation pathways were present with very different lifetimes; the longer lifetime was associated with one methyl-pyridinium head closer to the aryl rings, and the shorter lifetime was associated with the methyl-pyridinium head far from the aryl ring. The former ring is more shielded than the latter. Solution studies (UV/Vis, luminescence) and molecular modeling suggested that the calixarenes interact with the herbicide through cation- $\Pi$ interactions. Paraquat is included in the para-tert-butylcalix[8]arene cavity, but only partially included in the para-tert-butylcalix[6]arene cavity. The theoretical results, in particular using MOPAC procedures, were in good agreement with experimental findings. 
The preliminary test in water suggests that the stability of the PQ-para-tertbutylcalix[8]arene complex does not depend on the $\mathrm{pH}$ while that of PQ-para-tertbutylcalix[6]arene does. Being the former complex much more stable than the latter in aqueous media, we envision that para-tert-butylcalix[8]arene could be useful in stabilizing paraquat dichloride in solid, organic or water solutions to deposit/de-activate it as waste.

\subsection{Stoichiometry of extracted species formed with organic substrates and calixarenes}

Calixarenes have been used to separate organic pesticides, pharmaceuticals and dyes that pollute water. However, little attention has been dedicated to the stoichiometric ratio of the extracted species. Here, two examples are presented.

Shimojo \& Goto (2005) studied the synergistic extraction of nucleobases by a combination of calixarene and D2EHPA ligands. Liquid-liquid extraction of various nucleobases with a para-tert-octylcalix[6]arene carboxylic acid derivative was carried out to elucidate its molecular recognition properties. Bis-(2-ethylhexyl)phosphoric acid (D2EHPA) was tested as a synergistic reagent to improve the extraction capability of the calixarene toward nucleobases (in buffered water). The efficiency of adenine and cytosine extraction increased drastically in the presence of both extractant ligands dissolved in isooctane. Neither calix[6]arene nor D2EHPA were very effective at nucleobase extraction. According to Job's method, the stoichiometry of the extracted stable species in the case of the better-extracted adenine was 1 adenine:1 calix[6]arene:2 D2EHPA. The authors proposed that D2EHPA is involved in the secondary coordination sphere of the calixarene-adenine complex and that its highly hydrophobic nature enhances the distribution of the complex into isooctane. Recovery of adenine from the organic phase to the aqueous receiving phase is readily achieved under acidic conditions. These results highlight the great potential of macrocyclic ligand calixarenes as extractants for bioproducts.

As seen above, calixarenes are relevant to the removal of biological or pharmaceutical compounds from wastewater. Elsellami et al. (2009) implemented a coupling process between solid-liquid extraction and photocatalytic degradation for the selective separation of amino acids from water by calix [ $n$ ] arene carboxylic acid derivatives and degradation by activation of a photocatalyst $\left(\mathrm{TiO}_{2}\right)$ under UV light. The advantage of this liquid-solid extraction is that it selectively preconcentrates pollutants (tryptophan, phenyalanine and histidine). Apparently, the extracted complex was stabilized in a stoichiometric ratio of 1 calixarene: 1 amino acid. The photodegradation followed a first-order kinetic, and the rate constant increased with amino acid concentration. Clearly, solid-liquid extraction is a simple, useful method, and the reagents are recyclable. Although these results are only preliminary, they suggest further possibilities for optimal extraction of amino acids and other pharmaceuticals.

\subsection{Stoichiometry in calixarene complexes formed with metallic substrates in solution}

Several books and reviews on calixarenes have been dedicated to the coordination chemistry of calixarenes with most of the metal elements of the periodic table (Alexandratos \& Natesan, 2000; Lumetta et al., 2000; Mandolini and Ungaro, 2000; Mokhtari et al., 2011a, 2011b; Sliwa, 2002; Sliwa \& Girck, 2010; Talanova, 2000). The most important feature of 
functionalized calixarenes for coordination with metal ions is that metal complexation properties depend not only on the nature of the binding groups grafted to the calixarene platform but also on their stereochemical arrangement, determined by the calixarene conformation and regulated by its size. The coordination ability of the calixarene can be completely changed, when functionalized by the same groups, by simply changing the rim these groups are attached to; the stability, selectivity and stoichiometric ratio of the metal calixarene complexes will be consequently altered. Metal ions can be highly toxic pollutants, pesticides, radionuclides, materials, nanomaterials, oligoelements, and motivate the current interest in synthesizing calixarenes with enhanced selectivity in the liquid and solid states.

\subsubsection{Stoichiometric ratio with alkali and earth alkaline and metal transition ions}

Joseph et al. (2009) synthesized an amide-linked lower rim 1,3-bis(2-picolyl)amine calix[4]arene derivative. Binding properties of this ligand toward ten different biologically relevant metal ions $\mathrm{Mnn}^{2+}, \mathrm{Fe}^{2+}, \mathrm{Co}^{2+}, \mathrm{Ni}^{2+}, \mathrm{Zn}^{2+}, \mathrm{Cu}^{2+}, \mathrm{Na}^{+}, \mathrm{K}^{+}, \mathrm{Ca}^{2+}$, and $\left.\mathrm{Mg}^{2+}\right)$ have been studied by fluorescence and absorption spectroscopy in methanol and aqueous methanol. This ligand is a highly discriminating fluorescence sensor that selectively detects $\mathrm{Cu}^{2+}$ down to a concentration of 196 and $341 \mathrm{ppb}$ in methanol and 1:1 aqueous methanol, respectively, even if other metal ions are present. Based on competitive metal ion titration studies, $\mathrm{Cu}^{2+}$ can be sensed even in the presence of other biologically relevant ions in aqueous solution. Both the calix[4]arene platform and the pyridyl binding core are required for selective recognition of $\mathrm{Cu}^{2+}$, as established by comparison of results obtained with the relevant control molecules e.g. the upper-rim-based quinoline derivative. The stoichiometry of the complex was 1:1, as calculated by a Job plot and confirmed by ESI MS. The computationally obtained structure for the $\mathrm{Cu}^{2+}$ complex exhibited a tetracoordinate geometry that is also seen in the blue copper protein, i.e. plastocyanin.

Dendrimers and hyperbranched molecules special properties come from their very peculiar molecular structures. Their structures have been accurately defined, and are prepared by established reactions and chosen pathways. In preliminary work, Mahouachi et al. (2006) investigated the extraction of solid zinc(2+) picrate hydrate into $\mathrm{CDCl}_{3}$ solutions $\left(10^{-3} \mathrm{M}\right)$ by a linear dendrimer composed of six para-tertbutylcalix[4]arene linked together by amideethylene-amine and amide-ethylene chains. ${ }^{1} \mathrm{H}$ NMR spectra of the resulting solutions remained unchanged after 24 hours, indicating a stable complex. The integration ratio between the singlet of the picrate at $8.52 \mathrm{ppm}$ and the aromatic protons of the linear dendrimer indicates that the stoichiometry of the complex is 2:1 (metal:ligand). However, the spectrum of the complex was broad, and the signal patterns could not be interpreted. The authors proposed that this broadening was due to metal coordination site exchange, since the ligand has three potential $\mathrm{Zn}(2+)$-coordination sites, delineated by the amide functions and/or from a mixture of different arrangements of trinuclear complexes.

Sahin \& Yilmaz (2011) synthesized a new fluorogenic calixarene bearing two pyrene amine groups; the ligand shows selectivity for $\mathrm{Cu}^{2+}$ and $\mathrm{Pb}^{2+}$ due to a conformational change upon chelation of the ions. Absorption $\left(1 \times 10^{-4} \mathrm{M}\right)$ and fluorescence $\left(1 \times 10^{-6} \mathrm{M}\right)$ spectra of ligands in $\mathrm{CH}_{3} \mathrm{CN} / \mathrm{CH}_{2} \mathrm{Cl}_{2}$ solutions containing $10 \mathrm{~mol}$ equivalents of the appropriate metal perchlorate salt were recorded. The Job method was applied to determine the stoichiometry of the complexes, and the stability constants and quenching constants were determined by fluorimetric titration. When $\mathrm{Cu}^{2+}$ and $\mathrm{Pb}^{2+}$ are bound to the calixarene, the pyrene monomer 
and excimer decreased in a ratiometric manner. This ratiometric change is attributable to a combination of heavy metal ion effects, reverse-PET (photoinduced electron transfer) and conformational changes of the pyrene during the chelation of $\mathrm{Cu}^{2+}$ and $\mathrm{Pb}^{2+}$ to form the $1: 1$ complex. The authors conclude that this calixarene acts as a selective sensor of $\mathrm{Cu}^{2+}$ and $\mathrm{Pb}^{2+}$ ions. $\mathrm{Cu}^{2+}$ is both a pollutant and an essential trace element, while elevated levels of $\mathrm{Pb}^{2+}$ in the environment cause anemia, kidney damage, blood disorders, memory loss, muscle paralysis and mental retardation by lead poisoning.

Arena et al. (2003) functionalized the 1- and 3- positions of a calix[4]arene with two dipyridyl pendants to create a ligand that complexes $\mathrm{Cu}(2+)$ and $\mathrm{Co}(2+)$. The new ligand, fixed in its 1,3-alternate conformation, forms stable complexes with both $\mathrm{Co}(2+)$ and $\mathrm{Cu}(2+)$, as shown by $\mathrm{UV} / \mathrm{Vis}$ titrations carried out in acetonitrile. The stoichiometry of the main Co and $\mathrm{Cu}$-calixarene species was determined by molar ratio and Job plot methods. Both methods indicated a single complex species with a 1:1 stoichiometry for $\mathrm{Co}^{2+}$, and two complex species for $\mathrm{Cu}^{2+}$ in 1:1 and 2:1 (metal:ligand) stoichiometry. In the case of $\mathrm{Cu}^{2+}$, speciation was confirmed by the multivariate and multiwavelength treatment of the data (60-70 points) using two different software packages (Specfit and Hyperquad). The existence of two complexes with the above-mentioned stoichiometry was confirmed. The authors conclude that the new ligand efficiently targets ions, and proposed that the cobalt complex is a good candidate as di-oxygen carrier, while the two copper complexes are good low molecular weight model systems for the study of copper enzyme catalytic activity in nonaqueous environments. The extracted complex species with 1:1 stoichiometry is a good candidate for nanoswitches; cyclic voltammetry studies showed reversible oxidation/reduction behavior.

Kumar et al. (2010) reported fluorescent sensors based on ( $\mathrm{N}-($ pyrenyl-1-methylimine)derivatized calix[4] arenes and investigated their metal-ion binding $\left(\mathrm{Li}^{+}, \mathrm{Na}^{+}, \mathrm{K}^{+}, \mathrm{Pb}^{2+}, \mathrm{Zn}^{2+}\right.$, $\mathrm{Hg}^{2+}$ and $\mathrm{Ag}^{+}$) by UV and fluorescence spectroscopy in $\mathrm{CH}_{2} \mathrm{Cl}_{2} / \mathrm{CH}_{3} \mathrm{CN}$. Two of these receptors in a cone conformation showed ratiometric sensing while the third receptor in a 1,3 alternate conformation showed 'On-Off' signaling for $\mathrm{Pb}^{2+}$. The stoichiometry of $\mathrm{Pb}^{2+}$ with the three ligands was 1:1 as established by a Job's plot of fluorescence titrations. The cation binding properties of the ligands were examined by ${ }^{1} \mathrm{H}^{\prime} \mathrm{NMR}$ for $\mathrm{Pb}^{2+}$ in $\mathrm{CDCl}_{3}$ $/ \mathrm{CD}_{3} \mathrm{CN}(1: 9 \mathrm{v} / \mathrm{v})$. The significant downfield shift of the imino protons (>1.5 ppm) indicated strong complexation between imino nitrogen atoms and $\mathrm{Pb}^{2+}$ ions. Fitting the changes to the ligands fluorescence spectra with other metal ions using the nonlinear regression analysis program SPECFIT gave good fit with a 1:1 (metal:ligand) stoichiometry. The stability constant data indicated that these ligands bind strongly to $\mathrm{Pb}^{2+}$ ions. $\mathrm{Ag}^{+}$is bound to ligands more weakly than $\mathrm{Pb}^{2+}$, but more strongly than $\mathrm{Li}^{+}$.

Bayrakc1 et al. (2009) synthesized several dinitro-substituted calix[4]arene-based receptors for extracting chromate and arsenate anions. Chromate and arsenate anions are important because of their high toxicity and presence in soil and water. Humans are sensitive to arsenic carcinogenesis; prolonged exposure to arsenic damages the central nervous system and results in liver, lung, bladder, and skin cancers.

Chromium(6+) can be toxic, as it can diffuse as $\mathrm{Cr}_{2} \mathrm{O}_{7}{ }^{2-}$ or $\mathrm{HCr}_{2} \mathrm{O}_{7^{-}}$through cell membranes to oxidize biological molecules. Therefore, the treatment of waste water containing $\mathrm{Cr}(6+)$ prior to discharge is essential. The upper and lower rims of para-tert-butylcalix[4]arene (L) were modified in order to create binding sites for the recognition of arsenate and dichromate 
anions. Protonated alkylammonium forms of the ionophores showed high affinity toward dichromate and arsenate anions. Both oxyanions were extracted; extraction of the dichromate ions from water into dichloromethane follows a linear relationship between log $\mathrm{D}$ versus $\log [\mathrm{L}]$ at different concentrations of $\mathrm{L}$, with the slope $\approx 1$ at $\mathrm{pH}=1.5$, suggesting that two calixarenes form 1:1 complexes with the extracted dichromate anion.

Table 2 summarizes the stoichiometric ratio of some of the discussed metal complexes in solution.

\begin{tabular}{|c|c|c|c|}
\hline Substrate & Techniques/Solvent & $\begin{array}{l}\text { Methods/ } \\
\text { Stoichiometry(M:L) }\end{array}$ & References \\
\hline $\begin{array}{l}\mathrm{Cu}^{2+} / \text { amide linked lower } \\
\text { rim 1,3-bis(2-picolyl)amine } \\
\text { calix[4] }\end{array}$ & $\begin{array}{l}\text { Fluorescence, } \\
\mathrm{UV} / \mathrm{Vis} ; \mathrm{CH}_{3} \mathrm{OH} ; \\
\mathrm{CH}_{3} \mathrm{OH}-\mathrm{H}_{2} \mathrm{O}\end{array}$ & $\begin{array}{l}\text { Job plot/ ESI-MS } \\
/(1: 1)\end{array}$ & $\begin{array}{l}\text { Joseph et al., } \\
2009\end{array}$ \\
\hline $\begin{array}{l}\mathrm{Cu}^{2+} \text { and } \mathrm{Pb}^{2+} / \text { pyrene- } \\
\text { armed calix [4]arene } \\
\text { derivatives }\end{array}$ & $\begin{array}{l}\text { Fluorescence titration } \\
/ \mathrm{CH}_{2} \mathrm{Cl}_{2} / \mathrm{CH}_{3} \mathrm{CN}\end{array}$ & Job plot/ (1:1) & $\begin{array}{l}\text { Sahin \& } \\
\text { Yilmaz, } 2011\end{array}$ \\
\hline $\begin{array}{l}\mathrm{Co}^{2+} \text { and } \mathrm{Cu}^{2+} / 1,3- \\
\text { calix[4]arene with two } \\
\text { dipyridyl pendants }\end{array}$ & $\begin{array}{l}\text { UV/Vis titration/ } \\
\mathrm{CH}_{3} \mathrm{CN}\end{array}$ & $\begin{array}{l}\text { Job plot/ Specfit / } \\
\text { Hyperquad } / \mathrm{Co}_{2}{ }^{+1} \\
(1: 1) \mathrm{Cu}^{2+}(1: 1,2: 1)\end{array}$ & $\begin{array}{l}\text { Arena et al., } \\
2003\end{array}$ \\
\hline $\begin{array}{l}\mathrm{Li}^{1+}, \mathrm{Na}^{1+}, \mathrm{K}^{1+}, \mathrm{Pb}^{2+}, \mathrm{Zn}^{2+}, \\
\mathrm{Hg}^{2+}, \mathrm{Ag}^{2+} /(\mathrm{N}-(\text { pyrenyl } \\
\text { methylimine)calix[4] }\end{array}$ & $\begin{array}{l}\text { Fluorescence titration } \\
/ \mathrm{CH}_{2} \mathrm{Cl}_{2} / \mathrm{CH}_{3} \mathrm{CN}\end{array}$ & $\begin{array}{l}\text { Job plot/Specfit/ } \\
(1: 1)\end{array}$ & $\begin{array}{l}\text { Kumar et al., } \\
2010\end{array}$ \\
\hline $\begin{array}{l}\text { Cromate; Arsenate } \\
\text { anions/ dinitro - } \\
\text { substituted calix[4]arene }\end{array}$ & $\begin{array}{l}\text { UV/Vis , Atomic } \\
\text { absorption }\end{array}$ & $\begin{array}{l}\text { Liquid-liquid } \\
\text { extraction / (1:1) }\end{array}$ & $\begin{array}{l}\text { Bayrakc1 et } \\
\text { al., } 2009\end{array}$ \\
\hline $\begin{array}{l}\text { Ln/tetraphosphinoylated } \\
\text { paratertbutylcalix[4]arene }\end{array}$ & $\begin{array}{l}\mathrm{UV} / \mathrm{Vis}, \mathrm{NMR}, \mathrm{ES}-\mathrm{MS} \\
\text { titrations } / \mathrm{CH}_{3} \mathrm{CN}\end{array}$ & Specfit/ $(1: 1,1: 2)$ & $\begin{array}{l}\text { Le Saulnier } \\
\text { et al., } 1999\end{array}$ \\
\hline $\begin{array}{l}\text { Ln/ tetra-ether-amide- } \\
\text { paratertbutylcalix[4]arene }\end{array}$ & $\begin{array}{l}\text { NMR titration/ } \\
\mathrm{CH}_{3} \mathrm{CN}\end{array}$ & $\begin{array}{l}\text { MINEQL }^{+} \\
\text {program/(1:1) }\end{array}$ & $\begin{array}{l}\text { Ramirez et } \\
\text { al., } 2001\end{array}$ \\
\hline $\begin{array}{l}\text { Ln/ hexaphosphinoylated } \\
\text { paratertbutylcalix[6]arene }\end{array}$ & $\begin{array}{l}\mathrm{UV} / \text { Vis titration/ } \\
\mathrm{CH}_{3} \mathrm{CN}\end{array}$ & Specfit/ $(1: 1,1: 2)$ & $\begin{array}{l}\text { Ramirez et } \\
\text { al., } 2002\end{array}$ \\
\hline $\begin{array}{l}\text { Ln/octaphosphinoylated } \\
\text { paratertbutylcalix[8]arene }\end{array}$ & $\begin{array}{l}\text { MS,UV/Vis, NMR } \\
\text { titrations/ } \mathrm{CH}_{3} \mathrm{CN}\end{array}$ & Specfit/ $(1: 1,2: 1)$ & $\begin{array}{l}\text { Puntus et al., } \\
2007\end{array}$ \\
\hline $\begin{array}{l}\text { An/hexaphosphinoylated } \\
\text { paratertbutylcalix[6]arene } \\
\text { An, } \mathrm{Ln} / \mathrm{B}_{6} \mathrm{bL}^{6}\end{array}$ & $\begin{array}{l}\text { UV/Vis titration/ } \\
\mathrm{CH}_{3} \mathrm{CN} \\
\mathrm{UV} / \mathrm{Vis}\end{array}$ & $\begin{array}{l}\text { Specfit/ }(1: 1,1: 2) \\
\text { Liquid-liquid } \\
\text { extraction/ }(1: 1)\end{array}$ & $\begin{array}{l}\text { Ramírez et } \\
\text { al., } 2008\end{array}$ \\
\hline $\begin{array}{l}\text { An, Ln/ phosphorylated } \\
\text { calixarenes (upper rim) } \\
\text { Ln,An/ phosphorylated } \\
\text { calixarenes (lower rim) }\end{array}$ & $\begin{array}{l}\text { Microcalorimetric, } \\
\mathrm{UV} / \text { Vis titrations/ } \\
\mathrm{CH}_{3} \mathrm{CN}, \mathrm{CH}_{3} \mathrm{OH}\end{array}$ & $\begin{array}{l}(1: 1,1: 2) \\
(1: 1,1: 2 \text { or } 2: 1)\end{array}$ & $\begin{array}{l}\text { Karavan et } \\
\text { al., } 2010\end{array}$ \\
\hline $\begin{array}{l}\text { An, Ln/ phosphorylated } \\
\text { calixarenes (lower and } \\
\text { upper rims) }\end{array}$ & $\mathrm{UV} / \mathrm{Vis}$ & $\begin{array}{l}\text { Liquid-liquid } \\
\text { extraction }(1: 1,1: 2)\end{array}$ & \\
\hline
\end{tabular}

Table 2. Stoichiometry of metal calixarene species, in solution, and the used techniques for their identification and determination. 


\subsubsection{Stoichiometric ratio with lanthanide and actinide ions in liquid and solid states}

In the last decade, many functionalized calixarenes have been used as lanthanide ion $(\operatorname{Ln}(3+))$ receptors, either to improve their photophysical properties by the antenna effect of the calixarene, or as selective extractants of Ln and actinides (An).

Le Saulnier et al. (1999) investigated the coordination chemistry of a tetraphosphinoylated para-tertbutylcalix[4]arene $\left(\mathrm{B}_{4} \mathrm{bL}^{4}\right)$ with lanthanides, $\mathrm{Ln},(\mathrm{Ln}(3+)=\mathrm{La}$, Eu and $\mathrm{Tb})$ and their luminescence. The stoichiometry of the complexes, both in solution and in the solid state, was 1:1 and 1:2 (M: $\left.\mathrm{B}_{4} \mathrm{bL}^{4}\right)$, as demonstrated by UV/Vis, NMR and ES-MS titrations and by applying Specfit software to UV/Vis data to determine speciation and stability constants in acetonitrile. Although the isolated complexes were very stable, the calixarene did not sensitize the $\mathrm{Eu}$ and $\mathrm{Tb}$ luminescence of the complexes.

Ramírez et al. (2001) prepared a tetra-ether-amide-para-tertbutylcalix[4]arene $\left(\mathrm{L}=\mathrm{A}_{4} \mathrm{bL}^{4}\right)$ and studied its coordination ability toward $\operatorname{Ln}(3+)=\mathrm{Eu}, \mathrm{Gd}, \mathrm{Tb}$, and $\mathrm{Lu}$. The stoichiometry of the complex species in acetonitrile solution was demonstrated to be $1: 1(\mathrm{M}: \mathrm{L})$ by ${ }^{1} \mathrm{H}^{\prime}-{ }^{13} \mathrm{C}-$ NMR and ES-MS titrations. The stability constants of the 1:1 species were estimated using the MINEQL ${ }^{+}$program. $\mathrm{A}_{4} \mathrm{bL}^{4}$ reacted with $\mathrm{Ln}(3+)$ in acetonitrile to yield a 1:1 complex. The crystal structure of the lutetium complex $\left[\mathrm{Lu}\left(\mathrm{A}_{4} \mathrm{bL}^{4}\right)\left(\mathrm{H}_{2} \mathrm{O}\right)\right]\left(\mathrm{CF}_{3} \mathrm{SO}_{3}\right)_{3} 2 \mathrm{Et}_{2} \mathrm{O}$ corroborated the 1:1 stoichiometry and showed the metal ion encapsulated in the cavity formed by the four arms. Lu was 9-coordinate, bound to the four ether and four carbonyl functions and a water molecule that was itself $\mathrm{H}$-bonded to the phenolic ether functions, rigidifying the cavity formed by the pendant arms. Additionally, an ether molecule is inserted into the hydrophobic cavity defined by the aromatic rings. Both NMR (La, Lu) and luminescence $(\mathrm{Eu}, \mathrm{Tb})$ data pointed to high local symmetry at the metal center while lifetime determinations were consistent with the coordination of an inner-sphere water molecule.

Although the calixarene sensitized the luminescence of the $\mathrm{Tb}$ ion, the quantum yield measured in acetonitrile was relatively low $\left(Q_{\mathrm{abs}}=5.8 \%, \tau_{\mathrm{F}}=1.42 \mathrm{~ms}\right)$, particularly for $\mathrm{Eu}$ $\left(Q_{\mathrm{abs}}=2.0 \%, \tau_{\mathrm{F}}=0.73 \mathrm{~ms}\right)$. This is most likely due to the presence of a ligand metal charge transfer (LMCT) state that severely limits such a process. This study demonstrated once more the calixarene platform potentiality to simultaneously complex inorganic and organic guests. This finding might be helpful for modeling and designing extraction processes.

A hexaphosphinoylated para-tertbutyl calix[6]arene $\left(\mathrm{B}_{6} \mathrm{bL}^{6}\right)$ was synthesized by Ramírez et al. (2002). Temperature-dependent ${ }^{1} \mathrm{H}$ and ${ }^{31} \mathrm{P}$ NMR studies indicate a mixture of conformers with a time-averaged $C_{6 \mathrm{v}}$ symmetry at $405 \mathrm{~K}$ in dmso- $\mathrm{d}_{6} ; \Delta G^{\neq}$values for conformational inter conversion processes were equal to 68(1) and 75(2) $\mathrm{kJ}^{-1} \mathrm{~mol}^{-1}$ and reveal a semi-flexible macrocycle with alternate in-out cone conformation in DMSO and $\mathrm{CHCl}_{3}$ solutions, confirmed by molecular mechanics and dynamics calculations. $\mathrm{B}_{6} \mathrm{bL}^{6}$ crystallized as a dimer, where the two calixarenes are linked through hydrogen bonding and surrounded by water and toluene molecules in the lattice. $\mathrm{UV} / \mathrm{Vis}$ spectrophotometric titration of $\mathrm{B}_{6} \mathrm{bL}^{6}$ with $\mathrm{La}(3+)$ in acetonitrile yielded stability constants of $\log \beta_{1}=9.8$ and $\log \beta_{2}=19.6$ for the $1: 1$ and $1: 2\left(\mathrm{Ln}: \mathrm{B}_{6} \mathrm{bL}^{6}\right)$ species, respectively.

Complexes with $\mathrm{La}, \mathrm{Eu}, \mathrm{Gd}$ and $\mathrm{Tb}$ in 1:1 and 1:2 (M:calixarene) stoichiometries were isolated and characterized. Lifetime determinations of the $\mathrm{Eu}(3+)$ and $\mathrm{Tb}(3+)$ complexes in acetonitrile solution were consistent with no, or little, interaction of water molecules in the inner coordination sphere. The $\mathrm{B}_{6} \mathrm{bL}^{6}$ sensitized the luminescence of $\mathrm{Tb}(3+)\left(Q_{\mathrm{abs}}=4.8 \%, \tau_{\mathrm{f}}=2.1 \mathrm{~ms}, 1\right.$ : 
1 complex $)$ and $\mathrm{Eu}(3+)\left(Q_{\mathrm{abs}}=2.5 \%, \tau=2.0 \mathrm{~ms}, 1: 2\right.$ complex $)$ reasonably well in comparison with $\mathrm{B}_{4} \mathrm{bL}^{4}$. Molecular modeling calculations confirmed that the structure observed in the solid state, with phosphoryl groups interacting with water molecules, is a good model for the solution structure. The stability constants for the complexes with $\mathrm{La}(3+)$ were either smaller (1:1 complex) or equal (1:2) to the ones found for the corresponding $\mathrm{B}_{4} \mathrm{bL}^{4}$, in view of the larger flexibility of the calix[6]arene macrocycle. Photophysical properties were enhanced with respect to the smaller calix[4]arene, which opens the way for sensitive luminescence detection of these complexes, a definite advantage for quantifying extraction processes.

The coordination ability of the $\mathrm{B}_{6} \mathrm{bL}^{6}$ calixarene toward actinides was established by Ramírez et al. (2008). Spectrophotometric titration of uranyl with $\mathrm{B}_{6} \mathrm{bL}^{6}$ in $\mathrm{CH}_{3} \mathrm{CN}$ yielded $\log$ $\beta_{11}=7.1$ and $\log \beta_{12}=12.5$ for the $1: 1$ and 1:2 $\left(\mathrm{UO}_{2}{ }^{2+}: \mathrm{B}_{6} \mathrm{bL}{ }^{6}\right)$ species, respectively. $\mathrm{UO}_{2}{ }^{2+}$ and Th(IV) complexes with 1:1 and 1:2 (M:L) stoichiometries were isolated and characterized. Uranyl compounds only fulfilled their $\mathrm{CN}=8$ with $\mathrm{B}_{6} \mathrm{bL}^{6}$, while thorium compounds required coordinated nitrates and/or water molecules. The luminescence spectra, photophysical parameters and luminescence lifetimes of the uranyl complexes permitted an understanding of the coordination chemistry of these actinide calixarene complexes.

Energy transfer from the $\mathrm{B}_{6} \mathrm{bL}^{6}$ ligand to the uranyl ion was relevant in the $1: 1$ complex, with $Q_{\text {abs }}=2.0 \%$. The uranyl complex emission revealed biexponential decay for both complexes. The conclusion that we drew from this luminescence study and comparison with the emission spectra of uranyl nitrate recorded under various experimental conditions is that coordination of uranyl to the calixarene results in stabilization of its triplet state (heavy atom effect). This coordination promotes efficient energy transfer, although incomplete in the case of the 1:2 complex. Additionally, the macrocyclic molecule(s) provide(s) a protective environment, minimizing nonradiative deactivation processes.

A de-tert-butylated calix[6]arene $\left(\mathrm{A}_{6} \mathrm{~L}^{6}\right)$ fitted with six ether-amide pendant arms in the lower rim was synthesized and characterized in solution (Ramírez et al., 2004). NMR spectroscopic data point to the six phenoxide units adopting an average $D_{6 h}$ conformation on the NMR time scale (1,2,3-alternate conformation). According to Augmented MM3 molecular mechanics and MOPAC quantum mechanical calculations, $\mathrm{A}_{6} \mathrm{~L}^{6}$ is a ditopic ligand featuring two nonadentate coordination sites, each built from three pendant arms, and extending in opposite directions, with one arm above and the other below the main ring. $\mathrm{A}_{6} \mathrm{~L}^{6}$ reacted with $\mathrm{Ln}$ ions $\left(\mathrm{Ln}\left(3^{+}\right)=\mathrm{La}, \mathrm{Eu}\right)$ in acetonitrile to successively form $1: 1$ and 2:1 complexes. The isolated Eu 2:1 complex was luminescent $\left(Q_{\mathrm{abs}}=2.5 \%\right.$ in acetonitrile, upon ligand excitation), with bi-exponential luminescent decay, pointing to the presence of two differently coordinated metal ions, one with no bound water molecules, and the other one with two molecules bound.

According to molecular mechanics calculations, the more stable isomer was indeed asymmetric, with two nine-coordinate metal ions. Both Eu ions are bound to three bidentate arms and one monodentate triflate anion, but one metal ion completes its coordination sphere with two phenoxide oxygen atoms while the other uses two water molecules, which is consistent with IR spectroscopic and luminescence data. The two metal ion sites became equivalent in acetonitrile, and the relatively long lifetime $(1.35 \mathrm{~ms})$ indicates a coordination environment free of water molecules. The absence of substituents on the narrower rim of $\mathrm{H}_{6} \mathrm{~L}^{6}$ (calix[6]arene) allows easy interconversion between different conformers, through either the "tert-butyl through the annulus" or "narrower rim through the annulus" 
pathways that facilitate 2:1 complex formation. This work demonstrated that the stoichiometry of lanthanide complexes with calixarenes can be tuned by a narrow and/or wide rim substituents suitable choice.

Puntus et al. (2007) synthesized an octa-phosphinoylated para-tertbutylcalix[8]arene $\left(\mathrm{B}_{8} \mathrm{bL}^{8}\right)$, and its structure was studied in solution. According to temperature-dependent ${ }^{1} \mathrm{H}$ and $31 \mathrm{P}$ NMR spectroscopic data, the calix[8]arene adopts a so-called in-out cone conformation. Its coordination ability toward $\mathrm{Ln}(\mathrm{Ln}(3+)=\mathrm{La}, \mathrm{Eu}, \mathrm{Tb}, \mathrm{Lu})$ was probed by MS, UV/Vis and NMR spectroscopic titrations. Although both 1:1 (in the presence of triflate) and 2:1 (in the presence of nitrate) $\mathrm{Ln}: \mathrm{B}_{8} \mathrm{bL}^{8}$ complexes could be isolated in the solid state, it was clear from the titration results that the major species present in methanol (solubility problems prevented the study in acetonitrile) had a 1:1 stoichiometry (irrespective of the anion), and the minor species a 2:1 stoichiometry. Observation of the 2:1 species was consistent with the bimetallic complexes usually isolated with calix[8]arenes, but only in the presence of a nitrate counterion as a result of its bidentate chelating mode.

NMR spectroscopic data indicated a common conformation for the 1:1 complexes in solution. Ln ions were coordinated by four of the eight phosphinoyl arms, with a coordination sphere completed by methanol molecules or nitrate ions, as ascertained by IR and MS spectra. $\mathrm{B}_{8} \mathrm{bL}^{8}$ displayed a weak absorption at $360 \mathrm{~nm}$ that can be assigned to an intraligand charge-transfer (ILCT) state that is very sensitive to coordination. Photophysical data for the Eu 2:1 complex pointed to similar chemical environments provided by the metal ion sites and no coordinated water, contrary to what is observed in the 1:1 complex. In this work, optical electronegativity predicted the energy of the charge-transfer states in the lanthanide systems with inequivalent ligands, and extensive analysis of the vibronic satellites of the $\mathrm{Eu}\left({ }^{5} \mathrm{D}_{0} \rightarrow{ }^{7} \mathrm{~F}_{\mathrm{J}}\right)$ transitions allowed the authors to draw conclusions about $\mathrm{Eu}(\mathrm{III})$ coordination.

Karavan et al. (2010) investigated the binding properties of three series of phosphorylated calixarene derivatives (bearing phosphine oxide or phosphonate groups either at the wide or the narrow rims) toward some representative lanthanide and actinide ions in solution. Complexation was studied in single media (methanol and acetonitrile) followed by UV spectrophotometric and isoperibolic (micro)calorimetric titrations (ITC). Using upper rim phosphorylated calixarenes, it was found that the solvating ability of methanol and acetonitrile influences stoichiometry, number and constant stability of the europium complex species (1:1 and/or 2:1 M: L species). In a single solvent, the major influence on the stoichiometry of a complex is the length of the substituents bound to the OP groups.

No influence of calixarene size or substituent type in the upper rim was observed in the stoichiometry of uranyl calixarene species (1:1) when lower-rim-phosphorylated calixarenes were used in methanol, while in acetonitrile, a 2:1 species was found with the detertbutylated tetramer derivative. Similar stoichiometries were determined for europium complex species using the tertbutylated tetramer in methanol, where a 1:2 complex species formation was also observed.

Calorimetry was very useful for the determination of stoichiometries, particularly when complexation did not induce significant spectral changes. It also provided full thermodynamic characterization of the complex species in organic solution. The influence of some structural features of the ligands on the nature of the substituents as well as the condensation degree of the calixarene moiety on the complexation thermodynamic parameters were thus established. It is clear that wide rim and narrow rim phosphine oxide 
derivatives formed 1:1 complexes with europium and uranyl, accompanied in some cases with 2:1 complexes or 1:2 species with europium.

The stabilization origin of the complexes is quite different for the two cations and depends on the solvent. Whereas entropy terms are generally favorable in methanol for europium complexes, the entropy contributions appear to be very negative and hence unfavorable in acetonitrile. This finding indicates the importance of solvation/desolvation in the complexation process. In contrast, the stabilization of the uranyl complexes is mostly enthalpy-driven in both solvents.

\subsubsection{Stoichiometric ratio in extracted species formed with lanthanide and actinides ions}

Studies of metal ion separations using liquid-liquid and liquid-solid extraction systems and the evaluation of their experimental parameters-extraction percentage, distribution (coefficients) ratios, loading capacity and the stoichiometry of the extracted species among others - allow for gaining a complete physicochemical understanding of the extraction system and its applications.

Long-lived radionuclides, actinides in particular, are the most hazardous components of nuclear waste. The recovery of these elements from waste mass, alone or combined with other elements like lanthanides before disposal or reprocessing, would significantly enhance the ecological safety and efficiency of the nuclear fuel cycle. Phosphorylated calixarenes offer numerous possibilities for selective complexation of metal ions and will likely be essential in the treatment of nuclear waste.

Here, we focus on the Ln and An extracted species with phosphinoylated (phosphorylated) calixarenes from aqueous media to organic media. The usefulness of this type of calixarene for Ln/An separation with high efficiency was proved several years ago (Lumetta et al., 2000). The stoichiometry of extracted species with a certain calixarene is not necessarily in agreement with that of its complex species. Furthermore, a functionalized calixarene with the same phosphinoylated arms in the lower rim or in the upper rim does not extract a species with the same stoichiometry (Arnaud-Neu et al., 2000; Karavan et al., 2010).

Solvent can influence the conformational arrangement of the calixarene and thus the stabilization of certain complex species. It can also compete for metal ions, affecting the M:calixarene stoichiometric ratio. Experiments were conducted on the $\mathrm{B}_{6} \mathrm{bL}^{6}$ calixarene functionalized in the lower rim mentioned above (Ramírez et al., 2008) in a liquid-liquid extraction system of metal salt/1 $\mathrm{M} \mathrm{HNO}_{3} / 3.5 \mathrm{M} \mathrm{NaNO}_{3}$-calixarene in chloroform. A 1:1 stoichiometry was found for the $\mathrm{Eu}(3+), \mathrm{UO}_{2}{ }^{2+}$ and $\mathrm{Th}(4+)$ extracted species while the complexation study in acetonitrile demonstrated 1:1 and 1:2 complexes in the solution and solid state.

Karavan et al. (2010) found that for liquid-liquid extraction from nitric acid to mnitrobenzotrifluoride uranyl extracted species were in a 1:2 stoichiometry using a pentamer functionalized on the lower rim while in methanol and in acetonitrile the uranyl complex species were in 1:1 stoichiometry. However, europium extracted species kept the same stoichiometry. In contrast, upper-rim functionalized calixarenes using the same extraction system formed 1:1 uranyl extracted species and europium in 1:1 and 1:2 stoichiometries. Thus, the size, conformation, choice of rim (upper or lower), and length and isomeric nature 
of the aliphatic substituents, notwithstanding solvent effects, are all factors that define the stoichiometry of extracted species.

\section{Molecular modeling}

Jean Marie Lehn (Lehn, 1990) established that molecular recognition is key not only to biological macromolecules but also to macrocyclic complexation. Experimental results are sometimes not sufficient to elucidate how recognition occurs, which sites coordinate, how the stereochemical arrangement influences stabilization of the complex molecule, or why the substrate physicochemical properties drastically change after interaction with a certain macrocycle. Since suitable single crystals of macrocycle complexes are difficult to obtain, simulation of complexes with molecular modeling has become extremely useful. New molecular receptors can also be designed, built and optimized with the same software, although successful prediction depends on the molecule and the calculation approach used.

Molecular modeling is mostly useful when the molecule is based on experimental data. It has to be used with a great care to avoid meaningless results. The more complicated the molecule, the less likely the model is to represent the real complex. Before 1999, only empirical calculations were used for calixarene complexes, but over the last decade, ab initio and semi-empirical calculations have been successfully attempted.

Kunsági-Máte et al. (2004) used the HYPERCHEM Professional 7 and related quantumchemical calculations to elucidate the inclusion of $\mathrm{C}_{60}$ fullerene in the hexasulfonated calix[6]arene functionalized at the upper rim. The calculation showed that $\mathrm{C}_{60}$ lies deep in the cavity of the calixarene.

Zielenkiewicz et al. (2005) used INSIGHT II to show that a phosphorylated calix[4]arene effectively bound for the amino acid isoleucine. Based on the calculation results for 1:1 and 1:2 (isoleucine: calixarene) complexes, the inclusion of the isoleucine into the calixarene cavity stabilizes the macrocyclic skeleton in the regular cone conformation. Strong electrostatic interactions between the phosphoryl group of the calixarene and the positively charged amino group of the amino acid played an important role in the complexation process.

Atwood et al. (2005) visualized purely size-shape considerations with X-SEED to determine whether two $\mathrm{CH}_{4}$ molecules could fit within each dimeric capsule. The calculation illustrated the capsules' excellent size-shape compatibility.

To understand the structural features of the 1:1 complex formed between an amide-linked lower rim 1,3-bis(2-picolyl)amine derivative of calix[4] arene and $\mathrm{Cu}^{2+}$, Joseph et al. (2009) calculated the complex using GAUSSIAN 03 and DFT calculations. The calculated structure for the $\mathrm{Cu}^{2+}$ complex exhibited a tetracoordinate geometry, where all four pyridyl moieties were involved in binding and the coordination of $\mathrm{Cu}^{2+}$ center was a highly distorted tetrahedral.

Ding et al. (2011) calculated the most stable structures of the complex (the lowest energy was $0 \mathrm{kcal} / \mathrm{mol}$ ) formed between tetrabutyl ether derivatives of p-sulfonatocalix[4]arene $(\mathrm{SC} 4 \mathrm{Bu})$ and the methiocarb pesticide using GAUSSIAN 03. The complexation was an "external" inclusion process, and hydrogen bonding between the methyl $\mathrm{H}$ atom of methiocarb and the sulfonate of SC4Bu facilitated the formation of this SC4Bu-methiocarb complex. 
We have used molecular modeling in our current work with calixarenes and calixarene complexes. Structures have been built, and their minimum energies calculated, using the CAChe WorkSystem Pro 5.02 for Windows ${ }^{\circledR}$. Free calixarenes (Ramírez et al., 2004; Ramírez et al., 2008; García-Sosa \& Ramírez, 2010) and calixarenes complexed with organic substrates (García-Sosa \& Ramírez, 2010) have been simulated by sequential application of Augmented MM3/CONFLEX/Augmented MM3/ MOPAC/PM5 or PM3/ MOPAC/PM5 or PM3/COSMO procedures.

MOPAC/PM5 or PM3/COSMO procedures calculate the most stable molecules under aqueous solvent effects and the heat formation of the most stable molecule (given in $\mathrm{kcal}^{\mathrm{mol}} \mathrm{m}^{-1}$ ).

The calixarene complexes formed with lanthanide and actinide ions were calculated by sequential application of Augmented MM3/CONFLEX procedures (Ramírez et al., 2004; Ramírez et al., 2008). Augmented MM3 yielded the optimum structure, and CONFLEX yielded the most stable conformers $\left(\mathrm{kcal}_{\mathrm{mol}} \mathrm{m}^{-1}\right)$.

Fig. 4 shows the modeled structure of the de-tert-butylated calix[6]arene fitted with six ether amide pendant arms, $\mathrm{A}_{6} \mathrm{~L}^{6}$ (Fig. 4, left) and its europium complex in a 2:1 (metal: ligand) stoichiometry (Fig. 4, right). The modeling shows that the free calixarene is a ditopic ligand featuring two nonadentate coordination sites; each is built from three pendant arms and extends in opposite directions, one site above, and the other under the main ring. The modeled structure of the dimetallic complex is a stable asymmetric isomer with two ninecoordinate metal ions.
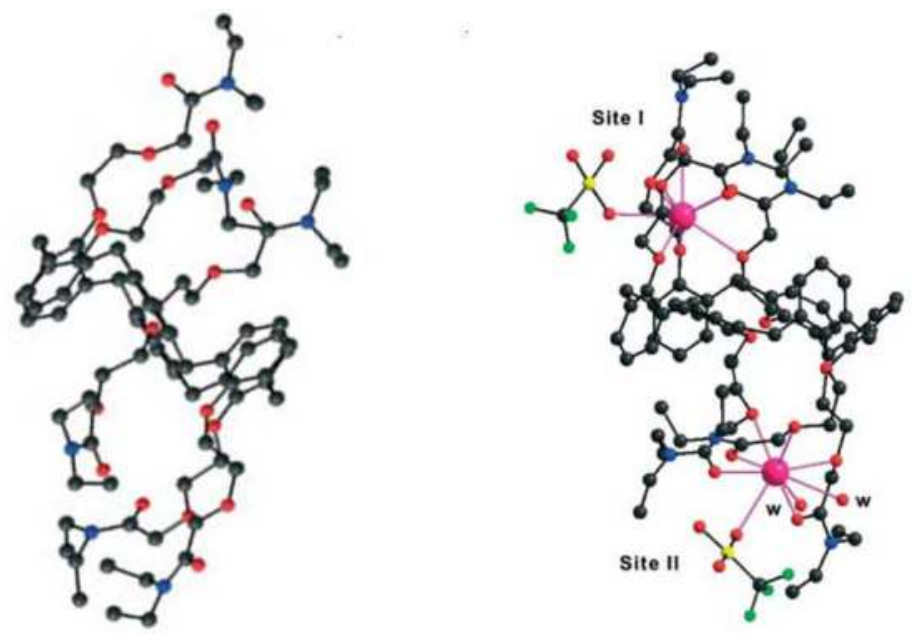

Fig. 4. Molecular modeling of $\mathrm{A}_{6} \mathrm{~L}^{6}$ calixarene (left) and optimized geometry of the $\mathrm{Eu}\left(3^{+}\right)$ 2:1 complex with $\mathrm{A}_{6} \mathrm{~L}^{6}$ (right), as determined by MM3 Augmented and Conflex CAChe procedures (Ramírez et al., 2004).

Both $\mathrm{Eu}(3+)$ ions are bound to three bidentate arms and one monodentate triflate anion, but one of the metal ion completes its coordination sphere with two phenoxide oxygen atoms whereas the other uses two water molecules. These computational results are consistent with IR and luminescence data (Ramírez et al., 2004) and elucidate the luminescence behavior of the complex in solid and in solution. 


\section{Conclusions}

The aim of this chapter was to establish the relevance of stoichiometric studies in understanding complexes formed, either in solution or in the solid state, between calixarene receptors and organic or metal substrates. Spectroscopic techniques are highly useful in investigating the stoichiometry of calixarene complexes. Nevertheless, many stoichiometric studies require more than one technique, or one that affords thermodynamic parameters. Computational calculations have gained an important place in determining the stoichiometry of calixarene complexes. Visualizing the structural arrangement of a calixarene complex with a particular stoichiometry can help elucidate how the platform of a conformational functionalized calixarene at the upper or lower rim can drastically change the physical, chemical or physicochemical properties of the complexed substrate. Great care must be taken in experimentally determining stoichiometry and in correlating these ratios with molecular modeling to avoid incorrect conclusions.

In this chapter we have focused our attention on investigations linking basic research to real problems, from pollution and water treatment, to nuclear waste treatment, fuel storage and luminescent materials. The presented examples were carefully chosen to provide sufficient knowledge of stoichiometric studies from the experimental, theoretical and applications point of view. Furthermore, these examples afford an understanding of the physical, chemical and stereochemical parameters that are responsible for the stoichiometry and structure of an organic calixarene complex or of a metal calixarene complex.

The relevancy of stoichiometry and structure of the discussed examples for their future applications is undoubted.

The increasingly interest in calixarenes resides in their versatile intrinsic properties allowing them to be functionalized and to envision their potential applications in different fields of science and technology. Particular attention has to be paid to the use of functionalized calixarenes in biomedical studies, particularly on the stoichiometry and structure of organic and/ or metal complexes with potential biomedical applications.

\section{Acknowledgment}

The authors thank CONACYT (México), project Nr. 36689-E and the Swiss National Science Foundation project SCOPES No 7BUPJ062293; their works cited in this chapter were developed with their support. They also thanks to Mr. Claudio Fernández from the Library of ININ for his help anytime they needed it.

\section{References}

Alexandratos, S. D. \& Natesan, S. (2000). Coordination Chemistry of Phosphorylated Calixarenes and Their Application to Separations Science. Industrial \& Engineering Chemistry Research, Vol. 39, No. 11, (Sept. 2000), pp.3998-4010, DOI: 10.1021 /ie000294x.

Arena, G., Contino, A., Longo, E., Sciotto, D., Sgarlata C. \& Spoto G. (2003). Synthesis, Characterization of a Novel Calixarene Having Dipyridyl Pendants and Study of its Complexes with $\mathrm{Cu}(\mathrm{II})$ and $\mathrm{Co}(\mathrm{II})$. Tetrahedron Letters, Vol. 44, No. 29, (July 2003), pp. 5415-5418, ISSN: 0040-4039 
Arnaud-Neu, F., Barboso, S., Byrne, D., Charbonnière, L. J., Schwing-Weill, M. J. \&. Ulrich G. (2000). Binding of Lanthanides (III) and Thorium In: Calixarenes for Separations (2000) Lumetta G. J., Rogers R. D, Gopalan A. S., Editor(s) pp. 150-164, ACS Symposium Series Volume 757 American Chemical Society Washington D.C., ISBN: 0-8412-3660-7, United States of America

Asfari, M.-Z., Böhmer, V., Harrowfield J. \& Vicens J. (Eds.) Calixarenes 2001, 2001 ISBN: 07923-6960-2, Kluwer Academic Publishers The Netherlands

Atwood, J L., Barbour, L. J., Thallapally, P. K. \& Wirsiga, T. B. (2005). A Crystalline Organic Substrate Absorbs Methane under STP Conditions. Chemical Communications, (Jan. 2005), pp. 51-53, DOI: $10.1039 /$ b416752j

Bayrakc1, M., Ertul, S. \& Yilmaz M. (2009). Synthesis of Di-substituted Calix[4]arene-based Receptors for Extraction of Chromate and Arsenate Anions. Tetrahedron, Vol. 65, (Sept. 2009), pp. 7963-7968, ISSN: 00404020 DOI: 10.1016/j.tet.2009.07.062

Böhmer, V. (1995). Calixarenes, Macrocyles with (almost) Unlimited Possibilities. Angewandte Chemie International Edition in English, Vol. 34, No.7, (April 1995) pp. 713-745, DOI:0.1002/anie.199507131

Ding, X.-P., Tang, D.-B., Li, T., Wang, S.-F. \& Zhou Y.-Y. (2011). A Novel Spectrofluorometric Method for the Determination of Methiocarb Using an Amphiphilic psulfonatocalix[4]arene. Spectrochimica Acta Part A: Molecular and Biomolecular Spectroscopy (in press), ISSN: 1386-1425

Elsellami, L. Chartron, V., Vocanson, F., Conchon, P., Felix, C., Guillard, C., Retailleau, L. \& Houas, A. (2009). Coupling Process between Solid-liquid Extraction of Amino Acids by Calixarenes and Photo Catalytic Degradation. Journal of Hazardous Materials, Vol. 166, No. 2-3, pp. 1195-1200, ISSN: 0304-3894

Ferreira Machado, I.L., Vieira Ferreira, L.F. \& Oliveira, A.S. (2010). Luminescence and Diffuse Reflectance Studies of Biacetyl Included within p-tert-Butylcalixarenes. Journal of Luminescence, Vol. 130, (July 2010), pp. 2251-2255, DOI:10.1016/j.jlumin.2010.06.029

García-Sosa, I. \& Ramírez, F.de M. (2010). Synthesis, Solid and Solution Studies of Paraquat Dichloride Calixarene Complexes. Molecular Modelling. Journal of the Mexican Chemical Society, Vol. 54, No.3, (July-Sept. 2010), pp. 143-152, ISSN: 1870-249X

Gil, V. M. S. \& Oliveira, N. C. (1990). On the Use of the Method of Continuous Variations. Journal of Chemical Education, Vol. 67, No. 6, (June 1990), pp. 473-478, DOI: $10.1021 /$ ed067p473

Gutsche, C. D. Calixarenes revisited, Monographs in Supramolecular Chemistry, J. Frase Stoddart Series Ed. The Royal Society of Chemistry, London, 1998, ISBN: 0- 85404502-3

Gutsche, C. D. Calixarenes, Monographs in Supramolecular Chemistry J. Frase Stoddart Series Ed. The Royal Society of Chemistry, London, 1989, ISBN: 0-85186-916-5

Halder, A., Nayak, S. K., Chattopadhyay, S. \& Bhattacharya, S. (2010). UV-Vis and NMR Spectroscopic Investigations on Effective and Selective Non-Covalent Interactions between Fullerenes and Calix[6]arene. Journal of Molecular Liquids, Vol. 151, No. 2-3, (Feb. 2010), pp. 125-129, ISSN: 0167-7322.

Hill, Z. D. \& Mac Carthy, P. (1986). Novel Approach to Job's Method. Journal of Chemical Education, Vol. 63, No. 2, (Feb. 1986), pp. 162-167, DOI: 10.1021/ed063p162

Joseph, R., Ramanujam, B., Acharya, A. \& Rao, C. P. (2009). Fluorescence Switch-on Sensor for $\mathrm{Cu}^{2+}$ by an Amide Linked Lower Rim 1,3-bis(2-picolyl)amine Derivative of Calix[4]arene in Aqueous Methanol. Tetrahedron Letters, Vol. 50, No. 23, (June 2009), pp. 2735-2739, ISSN: 0040-4039 
Karavan, M., Arnaud-Neu, F., Hubscher-Bruder, V., Smirnov, I. \& Kalchenko, V. (2010). Novel Phosphorylated Calixarenes for the Recognition of f-Elements. Journal of Inclusion Phenomena and Macrocyclic Chemistry, Vol. 66, No.1- 2, pp. 113-123, ISSN: 0923-0750 (print version) ISSN: 1573-1111 (electronic version)

Kumar, M., Babu, J. N., Bhalla, V. \& Kumar, R. (2010). Ratiometric/‘On-Off' Sensing of Pb²+ Ion Using Pyrene-appended calix[4]arenes. Sensors and Actuators B, Vol. 144, No. 1, (Jan. 2010), pp.183-191, ISSN: 0925-4005

Kunsági-Máté, S., Szabó, K., Bitter, I., Nagy, G. \& Kollár, L. (2004). Complex Formation between Water-soluble Sulfonated Calixarenes and $\mathrm{C}_{60}$ Fullerene. Tetrahedron Letters, Vol. 45, No. 7, (Feb 2004), pp. 1387-1390, ISSN: 0040-4039

Le Saulnier, L., Varbanov, S., Scopelliti, R., Elhabiri, M. \& Bünzli, J-C G. (1999). Lanthanide Complexes with a p-tert-butylcalix[4]arene Fitted with Phosphinoyl Pendant Arms. Journal of the Chemical Society, Dalton Transactions, No. 22, pp. 3919-3925, DOI: 10.1039/A907693J

Lehn, J. M. (1990). Perspectives in Supramolecular Chemistry-from Molecular Recognition Towards Molecular Information Processing and Self-organization. Angewandte Chemie International Edition in English, Vol. 29, No. 11, (Nov. 1990), pp.1304-1319, DOI:10.1002/ANIE.199013041

Likussar, W. \&. Boltz, D. F (1971). Theory of Continuous Variations Plots and a New Method for Spectrophotometric Determination of Extraction and Formation Constants. Analytical Chemistry, Vol. 43, No. 10, (Aug.1971), pp. 1265-1272, DOI: 10.1021/ac60304a006

Lumetta, G. J., Rogers, R. D., Gopalan, A. S. Ed.(s) (2000). Calixarenes for Separations DOI: 10.1021/bk-2000-0757.fw001 ACS Symposium Series, Vol. 757, ISBN:13: 9780841236608

Mahouachi, M., Ben Othman, A., Thuéry, P., Abidi, R., Jung, J. H., Kim, J. S., \& Vicens, J. (2006). Novel calixarene-based Hyperbranched Molecules with N-multidentate Chelating Sites. Journal of Nano \& Bio Tech, Vol. 2, No. 1, (March 2006), pp. 17-23

Mandolini, L., Ungaro, R. Ed. (s). Calixarenes in Action (2000). World Scientific Pub Co. Inc ImperialCollege Press, ISBN: $186094194 X$

Mohammed-Ziegler, I., Poór, B., Kubinyi, M., Grofcsik, A., Grün, A. \& Bitter, I. (2003). Spectroscopic Study on the Complex Formation of Chromogenic Bridged Calixarenes with Aliphatic Amines. Journal of Molecular Structure, Vol. 650, No 1-3, (May 2003), pp. 39-44, ISSN: 0022-2860

Mokhtari, B., Pourabdollah, K. \& Dallali, N. (2011a). A Review of Calixarene Applications in Nuclear Industries Journal Radioanalytical and Nuclear Chemistry, Vol. 287, No. 3, pp. 921-934, DOI:10.1007/s10967-010-0881-1

Mokhtari, B., Pourabdollah, K. \& Dallali, N. (2011b). Analytical Applications of Calixarenes from 2005 up-to-date. Journal of Inclusion Phenomena and Macrocyclic Chemistry, Vol. 69, No. 1-2, pp 1-55, 0 DOI 10.1007/s10847-010-9848-7, ISSN: 09230750

Pacioni, N. L., Sueldo Occello, V. N., Lazzarotto, M. \& Veglia, A. V. (2008). Spectrofluorimetric Determination of Benzoimidazolic Pesticides: Effect of psulfonatocalix[6]arene and Cyclodextrins. Analytica Chimica Acta, Vol. 624, No. 1, (Aug 2008), pp. 133-140, ISSN: 0003-2670

Pierro, T., Gaeta, C., Troisi, F. \& Neri, P. (2009). Induced-fit Recognition by pcarboxylatocalix[4]arene Hosts. Tetrahedron Letters, Vol. 50, No.3, (Jan. 2009), pp. 350-353, ISSN: 0040-4039 
Puntus, L. N., Chauvin, A-S., Varbanov, S. \& Bünzli, J-C. G. (2007). Lanthanide Complexes with a Calix[8]arene Bearing Phosphinoyl Pendant Arms. European. Journal of Inorganic. Chemistry, No. 22, (Apr. 2007), pp. 2315-2326, ISSN: 1434-1948, ISSN: 1099-0682

Ramírez, F. de M., Charbonnière, L., Muller, G., Scopelliti, R. \& Bünzli, J.-C. G. (2001). A ptert-butylcalix[4]arene Functionalised at its Lower Rim with Ether-amide Pendant Arms Acts as an Inorganic-organic Receptor: Structural and Photophysical Properties of its Lanthanide Complexes. Journal of the Chemical Society, Dalton Transactions, (Oct. 2001), pp. 3205-3213, DOI: 10.1039/b105513p

Ramírez, F. M., Varbonov, S., Cécile, C., Muller, G., Fatin- Rouge, N., Scopelliti, R. \& Bünzli, J.-C. G. (2002). A p-tert-butylcalix[6]arene Bearing Phosphinoyl Pendant Arms for the Complexation and Sensitisation of Lanthanide Ions. Journal of the Chemical Society, Dalton Transactions, No. 23, (Sept 2002), pp. 4505-4513, DOI: 10.1039/B206238K

Ramírez, F. M., Charbonnière, L., Muller, G. \& Bünzli, J.-C. G. (2004). Tuning the Stoichiometry of Lanthanide Complexes with Calixarenes: Bimetallic Complexes with a Calix[6]arene Bearing Ether-amide Pendant Arms. European Journal of Inorganic Chemistry, (April 2004), pp.2348-2355, DOI: 10.1002/ejic.200300824

Ramírez, F. de M., Varbanov, S., Padilla, J. \& Bünzli, J-C G. (2008) Physicochemical Properties and Theoretical Modeling of Actinide Complexes with a para-tertbutylcalix[6]arene Bearing Phosphinoyl Pendants. Extraction Capability of the Calixarene toward f Elements. The Journal of Physical Chemistry B, Vol. 112, No. 35, (Aug. 2008), pp. 10976-10988, DOI: 10.1021/jp710848m

Sahin, O. \& Yilmaz, M., (2011). Synthesis and Fluorescence Sensing Properties of Novel Pyrene-armed Calix[4]arene Derivatives. Tetrahedron, Vol. 67, No. 19, ( May 2011), pp. 3501-3508, ISSN: 0040-4020

Shimojo, K. \& Goto, M. (2005). Synergistic Extraction of Nucleobases by the Combination of Calixarene and D2EHPA. Separation and Purification Technology, Vol. 44, No. 2, (July 2005), pp. 175-180, ISSN: 1383-5866

Shinkai, S. (1993). Calixarenes-The Third Generation of Supramolecules. Tetrahedron, Vol. 49, No. 40, pp. 8933-8968, ISSN: 0040-4020

Sliwa, W. \& Girek, T. J. (2010). Calixarene Complexes with Metal Ions. Journal of Inclusion Phenomena and Macrocyclic Chemistry, Vol. 66, pp. 15-41, DOI: 10.1007/s10847-0099678-7

Sliwa, W. (2002). Calixarene Complexes with Transition Metal, Lanthanide and Actinide Ions. Croatica Chemica Acta, Vol. 75, No. 1, pp. 131-153, ISSN: 0011-1643

Talanova, G. G. (2000). Phosphorus-Containing Macrocyclic Ionophores in Metal Ion Separations. Industrial $\mathcal{E}$ Engineering Chemistry Research, Vol. 39, No. 10, (Sept. 2000), pp. 3550 -3565, DOI: 10.1021/ie0001467

Zhou, Y., Xu, H., Yu, H., Chun, L., Lu, Q. \& Wang, L. (2008). Spectrofluorometric Study on The Inclusion Behavior of p-(p-carboxylbenzeneazo) calix[4]arene with Norfloxacin. Spectrochimica Acta Part A, Vol. 70, No. 2, (July 2008), pp. 411-415, ISSN: 1386-1425

Zielenkiewicz, W., Marcinowicz, A., Poznanski, J., Cherenok, S. \& Kalchenko, V. (2005). Complexation of Isoleucine by Phosphorylated Calix[4]arene in Methanol Followed by Calorimetry, NMR and UV-VIS Spectroscopies, and Molecular Modeling Methods. Journal of Molecular Liquids, Vol. 121, No.1, (July 2005), pp. 8 -14, ISSN: 0167-7322 


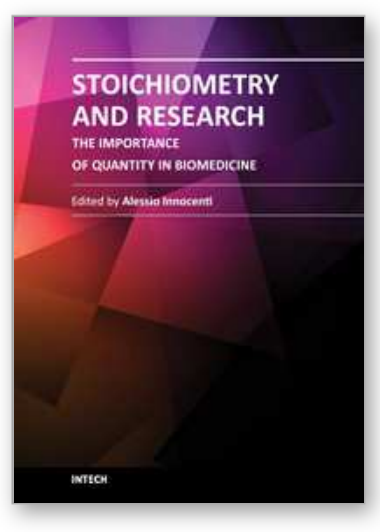

\section{Stoichiometry and Research - The Importance of Quantity in Biomedicine}

Edited by Dr Alessio Innocenti

ISBN 978-953-51-0198-7

Hard cover, 376 pages

Publisher InTech

Published online 07, March, 2012

Published in print edition March, 2012

The aim of this book is to provide an overview of the importance of stoichiometry in the biomedical field. It proposes a collection of selected research articles and reviews which provide up-to-date information related to stoichiometry at various levels. The first section deals with host-guest chemistry, focusing on selected calixarenes, cyclodextrins and crown ethers derivatives. In the second and third sections the book presents some issues concerning stoichiometry of metal complexes and lipids and polymers architecture. The fourth section aims to clarify the role of stoichiometry in the determination of protein interactions, while in the fifth section some selected experimental techniques applied to specific systems are introduced. The last section of the book is an attempt at showing some interesting connections between biomedicine and the environment, introducing the concept of biological stoichiometry. On this basis, the present volume would definitely be an ideal source of scientific information to researchers and scientists involved in biomedicine, biochemistry and other areas involving stoichiometry evaluation.

\section{How to reference}

In order to correctly reference this scholarly work, feel free to copy and paste the following:

Flor de María Ramírez and Irma García-Sosa (2012). Stoichiometric Ratio in Calixarene Complexes, Stoichiometry and Research - The Importance of Quantity in Biomedicine, Dr Alessio Innocenti (Ed.), ISBN: 978-953-51-0198-7, InTech, Available from: http://www.intechopen.com/books/stoichiometry-and-researchthe-importance-of-quantity-in-biomedicine/stoichiometric-ratio-in-calixarene-complexes

\section{INTECH}

open science | open minds

\section{InTech Europe}

University Campus STeP Ri

Slavka Krautzeka 83/A

51000 Rijeka, Croatia

Phone: +385 (51) 770447

Fax: +385 (51) 686166

www.intechopen.com

\section{InTech China}

Unit 405, Office Block, Hotel Equatorial Shanghai

No.65, Yan An Road (West), Shanghai, 200040, China

中国上海市延安西路65号上海国际贵都大饭店办公楼 405 单元

Phone: +86-21-62489820

Fax: +86-21-62489821 
(C) 2012 The Author(s). Licensee IntechOpen. This is an open access article distributed under the terms of the Creative Commons Attribution 3.0 License, which permits unrestricted use, distribution, and reproduction in any medium, provided the original work is properly cited. 